\title{
Ayak deformitelerinin tedavisi
}

\author{
Treatment of foot deformities
}

\author{
Bahtiyar Demiralp, Zafer Atbaşı \\ Ankara Özel Güven Hastanesi Ortopedi ve Travmatoloji Kliniği, Ankara
}

\begin{abstract}
Ayak, vücudun ağırlı̆̆ını taşıyan, yürümeyi sağlayan en önemli denge organıdır. Ayakta doğumdan itibaren çok farklı deformitelerle karşılaşılır. Bazı deformiteler tek planIı bazıları ise multiplanar deformitelerdir. Deformitenin tanınması ve olması gereken anatomik pozisyona getirilerek düzetilmesi gerekir. Ortopedik cerrahların normal ayak biyomekaniğinin değerlendirilmesinde kullanılan açıları bilerek değerlendirmesi, ayakta oluşan deformitenin tanımını yapabilmesi ve uygun tedavi yöntemlerini biyomekanik uyum içerisinde çözümleyebilmesi gerekir. Bu yazıda ayak deformitelenin tanımı, tanısı ve tedavi yöntemleri tartışıldı. Konjenital (clubfoot ve konjenital vertikal talus, çocuk felci, beyin felci, meningomyelosel ve Charcot-Marie-Tooth hastalığı) ve edinsel (travmatik yaralanmalar, osteomiyelit, nonunion veya malunion, bacak uzunluk farkı, yanık ve diğer yumuşak doku kontraktürleri, ateşli silah yaralanmaları) tek planlı (ekinus, kavus, planus, kalkaneusvarus, valgus) ve çok planlı ayak deformitelerinin (pes ekinovarus) tedavisinde uygulanacak yöntemler güncel litaratürler ile anlatıldı. Distraksiyon osteogenezisi ve İlizarov yöntemi ile deformite düzeltme teknikleri ve püf noktaları gözden geçirildi. Yöntemlerin avantajları, dezavantajları, endikasyonları ve komplikasyonları, karşılaşılabilecek zorluklar ve çözüm yöntemleri tartışıldı. Klinik deneyimlerimiz örneklerle anlatıldı.
\end{abstract}

Anahtar sözcükler: ayak; deformite; distraksiyon; biyomekanik; İlizarov
The foot is the most important balance organ that carries the weight of the body and provides walking. Many different deformities are encountered at foot since birth. Some of the deformities are single-plan while some are multiplanar. The deformity must be recognized and corrected by bringing it to the required anatomical position. Orthopedic surgeons should be able to know the angles used in the evaluation of normal foot biomechanics, to be able to define the deformity of the foot and to be able to analyze the appropriate treatment methods biomechanically. In this report, the definition, diagnosis and treatment methods of foot deformity are discussed. The methods to be used in the treatment of congenital (clubfoot and congenital vertical talus, polio, cerebral polsy, meningomyelocele and "Charcot-Marie-Tooth disease") and acquired (traumatic injuries, osteomyelitis, nonunion or malunion, leg length discrepancy, burns and other soft tissue contractures, gunshot wounds) single plan (equinus, cavus, planus, calcaneovarus, valgus) and multi-planted foot deformities (pes equinovarus) were explained with current literature. Distraction osteogenesis and deformity correction techniques with Ilizarov method and its tricks were reviewed. The advantages, disadvantages, indications and complications of the methods, the difficulties that may be encountered and the solution methods were discussed.

Key words: foot; deformity; distraction; biomechanic; llizarov

olur. Diz, kalça ve bel problemleri görülür. Ayak deformiteleri ayakkabı uyumunu bozar ve özel ayakkabı içi ortez gerektirir. ${ }^{[2]}$ Uygun olmayan basma nedeni ile, basınç noktaları nasırdan cilt ülserlerine kadar değişen cilt sorunlarına neden olur. Bu lezyonlar da enfeksiyon ve osteomiyelit ile komplike olabilir.

Ayak deformitelerinin tedavi amacı; stabil, ağrısız, plantigrad ve kozmetik olarak normal veya normale yakın bir yürüyüş sağlamaktır.

- Illetişim adresi: Uzm. Dr. Zafer Atbaşı, Ahmet Taner Kışlalı Mah. Alacaatlı Caddesi No:15, 06810 Çayyolu, Çankaya, Ankara Tel: 0532 - 7158681 e-posta: zatbasi@yahoo.com

- Geliștarihi: 25 Kasım 2019 Kabul tarihi: 20 Ocak 2020 


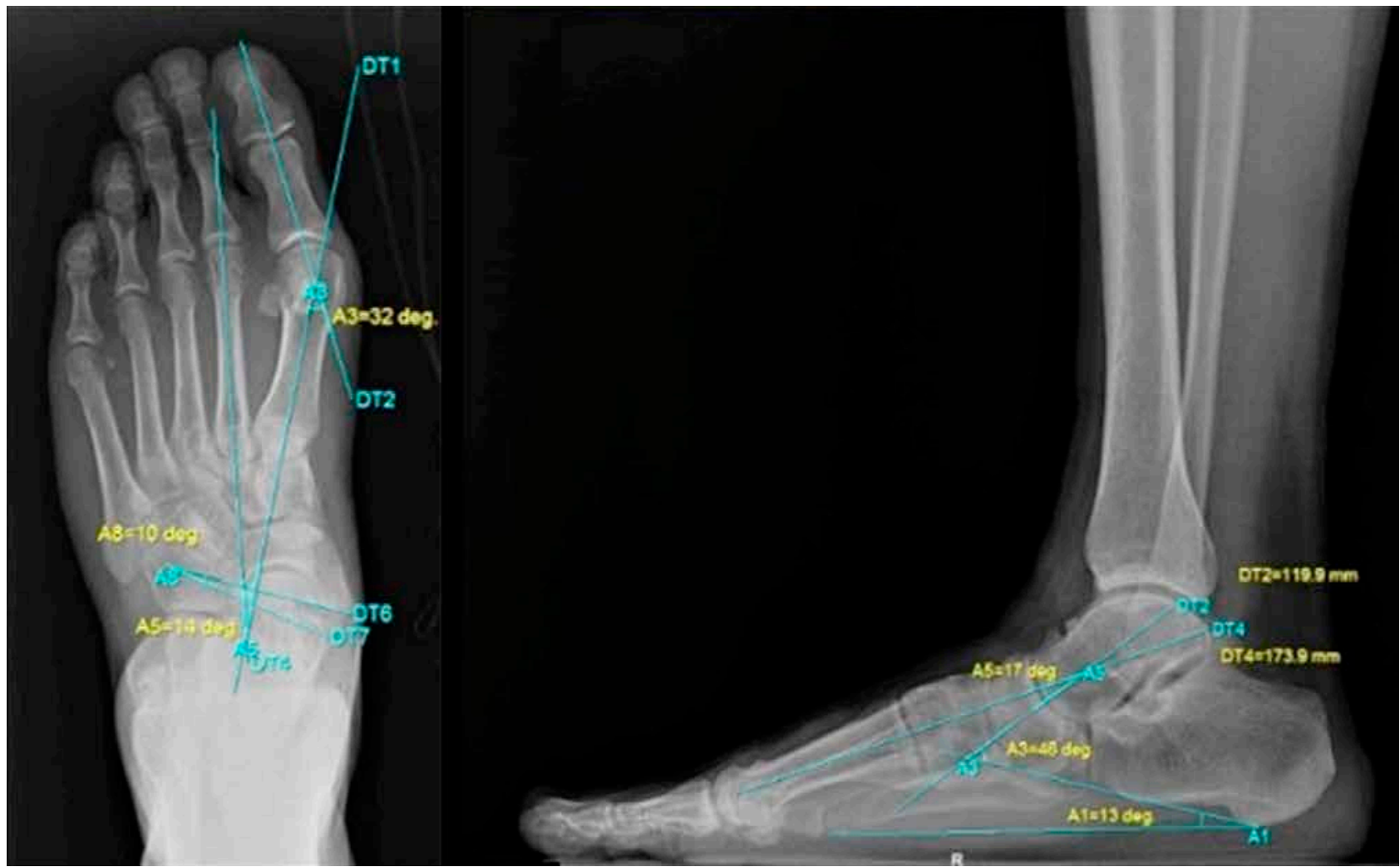

Şekil 1. Ayağın radyolojik değerlendirilmesi.

\section{BIYOMEKANIK}

Normal ayakta durma esnasında vücut ağırlığının \%50'si topuğa, \%50'si metatarsların distaline biner. Metatars distali de ağırlığı 1'den 5'e doğru 2-1-1-1-1 oranında taşır. Hafif bir topuklu ile 1. ve 5. metatarslar diğerlerine göre üç kat daha fazla yük taşır. Dolayısı ile sağlıksız bir ayakkabıda 1. ve 5. metatarslara daha fazla yük biner. ${ }^{[3]}$

Yapılan çalışmalarda ayak morfolojisinin ve antropometrisinin ayağın biyomekanik ölçümleri ile ilişkili olduğu bulunmuştur. Ayak boyu insan boyunun \%15,5'idir. Ayağın eni boyunun \%40'ıdır. ${ }^{[3]}$ Ayağın iki adet (medial ve lateral) longitudinal, bir adet de transvers yönde olmak üzere üç adet arkı, ayak kubbesini oluşturur. Lateral longitudinal arkı kalkaneus, kuboideum, dördüncü ve beşinci metatarsal kemikler; medial longitudinal arkı (MLA) ise kalkaneus, talus, naviküler, üç kuneiform kemik ve ilk üç metatarsal kemik oluşturur. Ayak kubbesini aktif olarak kaslar korurken pasif olarak bağlar korur. Ayak yapısına katkıda bulunan esas ark olan MLA, ön ayak ve arka ayak arasında elastik bir bağlantı sağlar. Bu da yük taşıma sırasında meydana gelen plantar kuvvetlerin çoğunun, uyluk ve bacak kemiklerine ulaşmadan önce dağılmasını sağlar. Pes kavus ve pes planus gibi spesifik olarak MLA'dan kaynaklanan problemler ve dizilim bozuklukları, sonuçta alt ekstremite kaslarının ve eklemlerinin işlevini etkiler. ${ }^{[4]} \mathrm{Bu}$ problemler edinilmiş veya yapısal nedenlerle olabilir. ${ }^{[5]}$ MLA'nın yapısında değişikliklere neden olan etkenlerin araştırılması halen devam etmektedir. Radyografik teknikler, ayağın iskeletsel hizalanmasının statik basarak pozisyonda değerlendirilmesinde altın standart olarak kabul edilmektedir. ${ }^{[6]}$ Günümüzde ayağın arkı değerlendirilirken sıklıkla radyolojik incelemelerde ölçülen çeşitli açılar dikkate alınır (Meary açısı, kalkaneal yükseklik açısı, talonaviküler örtünme açısı, lateral talokalkaneal açı) (Şekil 1). Ancak, bu incelemeler statik bir yöntemdir, ayağın dinamik yapısını yansıtmaz. Yürüme fonksiyonu karmaşık, dinamik bir harekettir ve son yıllarda ayak sorunlarını dinamik bir yöntem olan pedobarografi kullanarak değerlendirme giderek yaygınlaşmaktadır. ${ }^{[7,8]}$

Ayak hareketleri üç planda olmaktadır. Sagittal planda fleksiyon-ekstansiyon; koronal planda inversiyoneversiyon; horizontal planda abdüksiyon-addüksiyon hareketi yapar. 


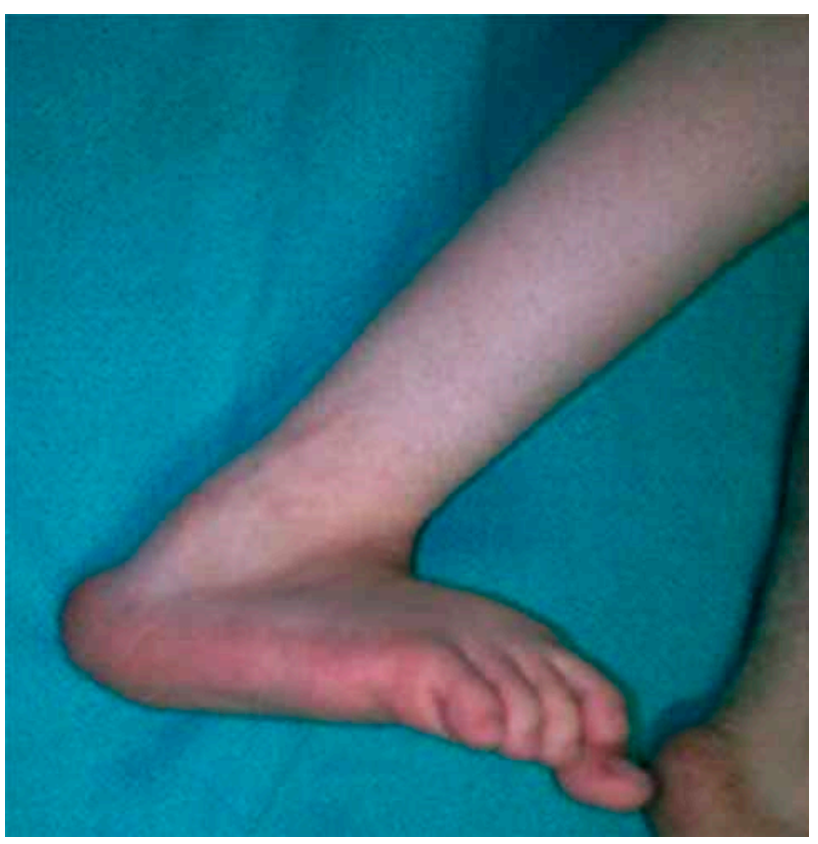

Şekil 2. Pes kalkaneus klinik görünüm.

\section{Sagittal Plan Deformiteleri}

Pes ekinus: Tibia-taban açısının $90^{\circ}$ 'den büyük olmasıdır.

Pes kavus: Ayağın ön kısmının arka kısmı ile olan ilişkisinde ekin pozisyonuna gelmesi veya kalkaneusun dorsifleksiyon durumuna gelerek vertikalleşmesidir. Kalkaneal yükseklik açısı ve Meary açısı ile tespit edilir.

Pes planus: Kalkaneusun plantar fleksiyon deformitesidir. Kalkaneus horizontalleşir. Medial ark düzleşmiştir.

Pes kalkaneus: Hastanın topuk üzerine basarak yürümesine ve yürürken ayağın ön bölümünün yere temas etmemesine denir. Kalkaneal yükseklik açısı $30^{\circ}$ 'nin üzerindedir ve ayak önü yere temas etmez (Şekil 2).

\section{Koronal Plan Deformiteleri}

Topuk varusu: Topuk alt yüzeyinin iç yana dönmesi ve aktif veya pasif olarak nötrale dönememesidir.

Topuk valgusu: Tibia longitüdinal ekseni ile kalkaneus longitüdinal ekseninin distale doğru birbirinden uzaklaşmasıdır.

\section{Horizontal Plan Deformiteleri}

Metatarsus adduktus: Ön ayağın arka ayağa göre daha fazla içe doğru deviye olmasıdır. Ön-arka grafide talusla 1. metatars arasında açı oluşur.

\section{CERRAHI TEKNIK}

Ayakta gelişen konjenital (doğumsal) veya edinsel deformiteler tek planlı veya multiplanar olabilir. Bu deformitelerin düzeltilmesi için birçok cerrahi teknik tarif edilmiştir. Deformitelerin ciddiyeti, şekil bozukluğu, hastanın yaşı, deformitenin sertliği, kas paralizisi veya eklemde artroz olup olmaması cerrahi teknik ve yumuşak doku prosedürlerini belirler. ${ }^{[5]}$

Kompleks deformitelerde üç planlı planlama ve sirküler eksternal fiksatör uygulaması, yumuşak doku problemlerini azalttığı gibi cerrahi sonrası da düzeltme olanağı sağlaması sebebi ile tercih edilen bir yöntemdir. ${ }^{[3]}$

\section{Sirküler Eksternal Fiksatör Uygulama Endikasyonları}

1- Ayak deformitelerinde sekonder osteoartrite bağlı oluşan ağrılar, kozmetik ve sosyoekonomik nedenler,

2- Belirgin kısalığı olan, wedge (kama) rezeksiyon gereken ve sonuçta kabul edilemeyecek kısalık oluşacak deforme ayaklar,

3- Skar ve trofik ülserlerle birlikte olan,

4- Kronik osteomiyelit hikâyesi olan,

5- Düzenli korreksiyona (düzeltmeye) uygun bilateral ayak deformiteleri

6- Yumuşak doku ve kemik kaybı ile birlikte olan yaralanmalara bağlı posttravmatik deformiteler.

\section{Sirküler Eksternal Fiksatör ile Distraksiyon Avantajları}

1- Minimal diseksiyon gerektirir (noninvazif).

2- Yumuşak doku problemleri, cilt kontraktürleri, enfeksiyon riski olan olgularda avantajlıdır.

3- Tedavi için iskelet yaşının tamamlanmasını beklemeye gerek yoktur.

4- Ameliyat süresi kısadır.

5- Tedavi süresince tam yük verilebilir.

6- Uygulanan tellerle osteolizis riski azdır, cihaz uzun süre tutulabilir.

7- Tüm deformite komponentleri aynı anda düzeltilebilir, postoperatif değişiklik yapma şansı vardır.

8- Klinik ve radyolojik tam düzelme sağlanana kadar korreksiyona (düzeltmeye) devam edilebilir.

9- Oluşabilecek komplikasyonlar kolaylıkla çözülebilir.

10- Kemik rezeksiyonu gerekmediğinden kısalık sorunu yoktur.

11- Kemik ve yumuşak dokular birlikte uzatılır, dolaşım problemi görülmez. 

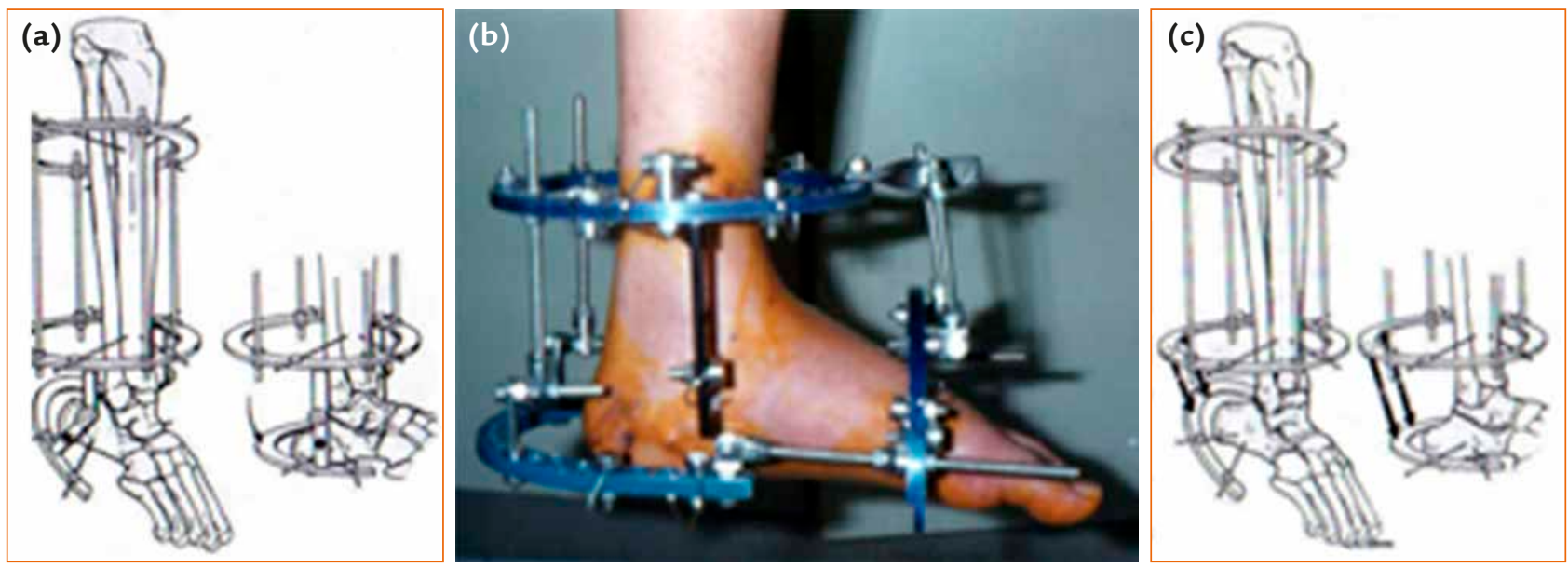

Şekil 3. a-c. Sınırlamalı (a). Sınırlamalı klinik (b). Sınırlamasız (c).

\section{Sirküler Eksternal Fiksatör ile Distraksiyon Dezavantajları}

1- Pin sorunları,

2- Uzamış immobilizasyon,

3- Distraksiyon periyodunda ağrı,

4- Ayak bileği ekleminde ek hareket kısıtlılığı.

Ayak deformiteleri sirküler eksternal fiksatör ile osteotomili veya osteotomisiz tedavi edilebilir.

\section{Osteotomisiz Teknik Endikasyonları}

1. Fizis distraksiyonu ve remodelizasyon şansı bulunan 8 yaşın altındaki çocuklar.

2. Fikse (Sabit) kemik deformitesi olmaması,

3. Düzgün eklem yapısı,

\section{Osteotomili Teknik Endikasyonları}

1. Sekiz yaşından büyük, yumuşak doku distraksiyonu ile düzgün eklem yüzeyi sağlanması mümkün olmayan fikse (sabit) kemik deformiteli çocuklar,

2. Yumuşak doku düzeltmesi sağlanmış, ancak korunamamış nöromusküler imbalanslı hastalar,

3. Eski füzyon veya nonunionların varlığı,

4. Çok rijit kontraktürlerde kemik düzeltilmesi gereksinimi.

Çerçeve (frame) iki şekilde hazırlanabilir.

Birincisi; sınırlamalı (constrained) ayak çerçevesi (Şekil 3 ). Menteşeler eklem seviyesine yerleştirilir. Rotasyon merkezini bulmak zordur. Hatalı uygulama ile eklemde dislokasyon, kompresyon riski vardır. İkincisi; sınırlamalı olmayan (unconstrained) ayak çerçevesi, Ayak bileği ve ayak eklemleri, deformite düzeltilmesinde menteşe görevini üstlenirler. Düzeltme, menteşe ve motor unite arasındaki eklemler boyunca olur.

Tek bir nokta veya eklemde oluşan özel bir deformitenin düzeltilmesi isteniyorsa sisteme sınırlamalar eklenebilir. Zeytinli tel kullanılarak tek eklem seviyesinde kontrollü korreksiyon sağlanabilir (Şekil 4).

Ayakta da düzeltme klasik olarak uzun kemik düzeltmesindeki gibi uygulanır. Kısa olan taraf uzatılarak hem düzeltme hem de uzatma sağlanır. Burada önemli olan düzeltmenin yapılacağı halkaya düzeltme yapılan taraftan zeytinli tel uygulanmasıdır. Böylelikle düzeltme sırasında telin kemiğin içine migre olması engellenmiş olur. Aynı şekilde destek halkaya da zeytinli tel uygulamak gerekir. ${ }^{[9]}$

Ayak uygulamalarında aparatlarda özellik arz eder. Genel olarak tibia alt uca bir halka yeterli gibi görünse de bu halkayı mutlaka ters klemp ile veya üçüncü bir tel ile desteklemek gerekir. En kolayı ve sağlamı yer problemi olmadığı için ikinci bir halka uygulamaktır. Kalkaneusa bir adet $5 / 8$ halka ve metatarslara da yukarıdan geçecek şekilde bir adet $1 / 2$ halka uygulanır. Bu şekilde üç adet komponent oluşturulmuş olur. Bu üç halka birbirine gerekirse kısaltıp uzatacak şekilde ikişer adet motor rodlar(çubuklar) ile bağlanır. Bu sayede her komponente üç boyutta da hareket verilebilir (Şekil 5). ${ }^{[10]}$

Gerekirse bir adet tel talustan geçilerek tibia halkasına klemp ile bağlanır. Bu ayak bilek hareket merkezinde olacağından düzeltme sırasında bilek hareketine izin verecektir. 

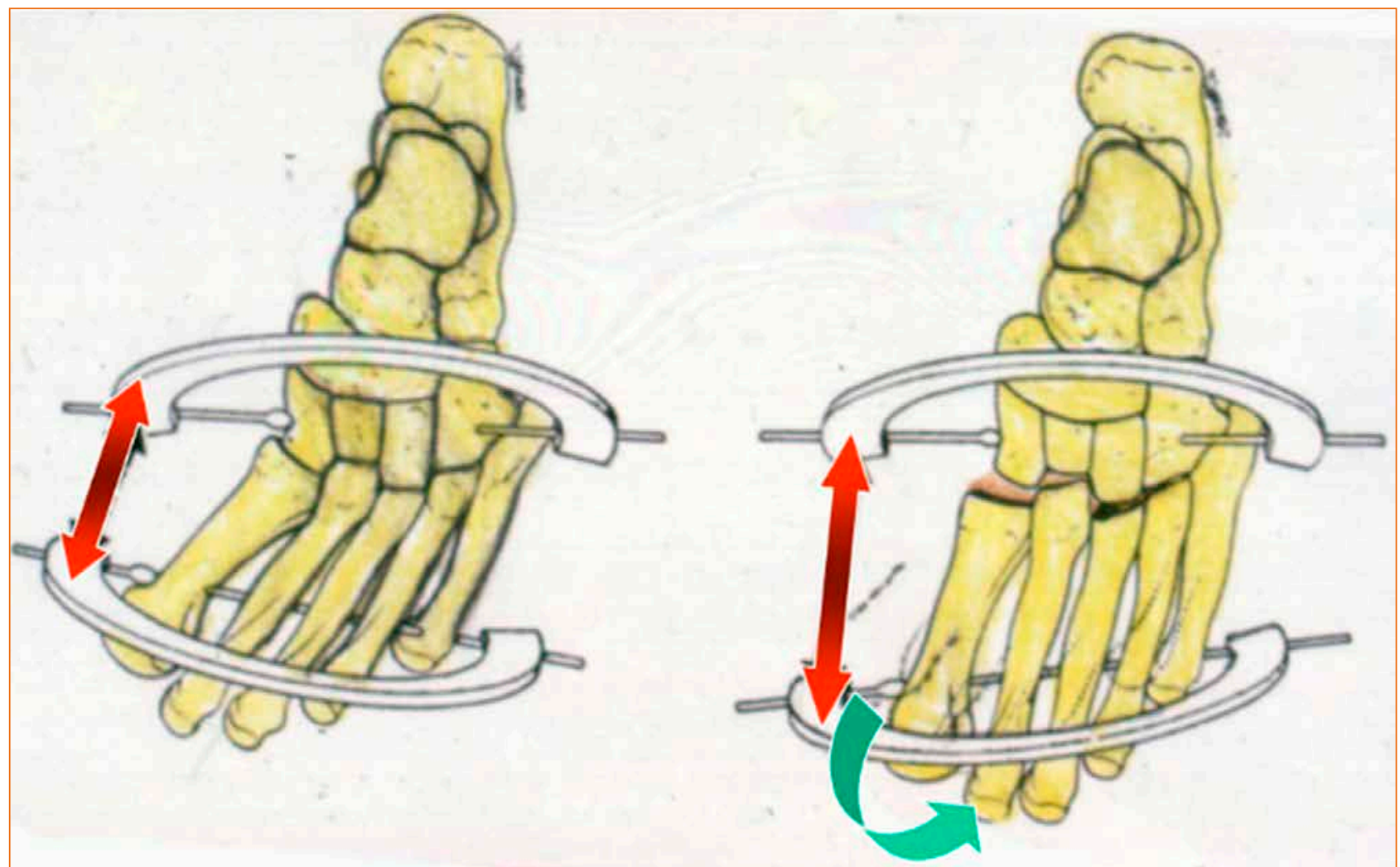

Şekil 4. Zeytinli tel uygulaması ile kontrollü distraksiyon.

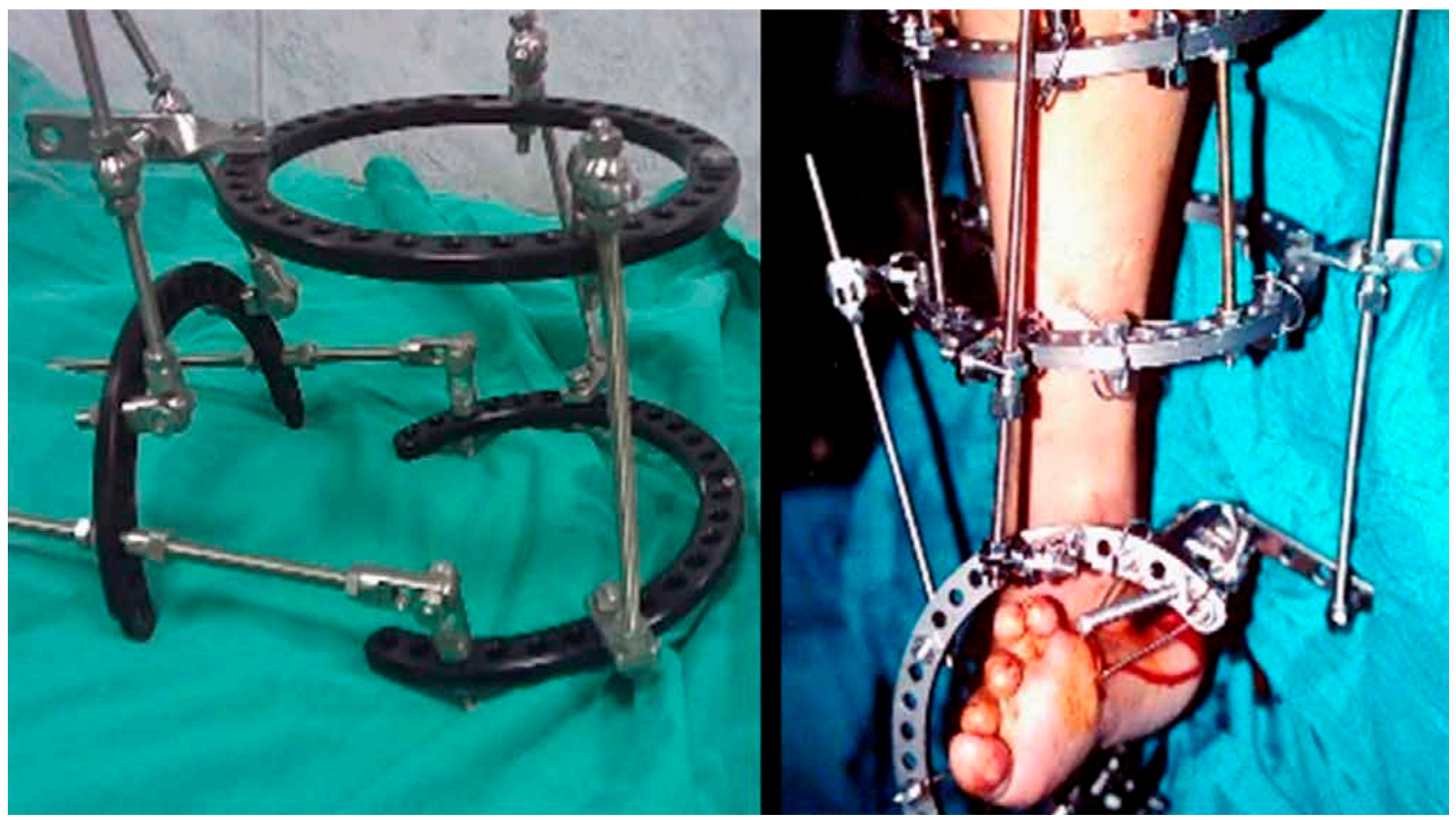

Şekil 5. Ayak deformitesinde kullanılan sirküler eksternal fiksatör. 


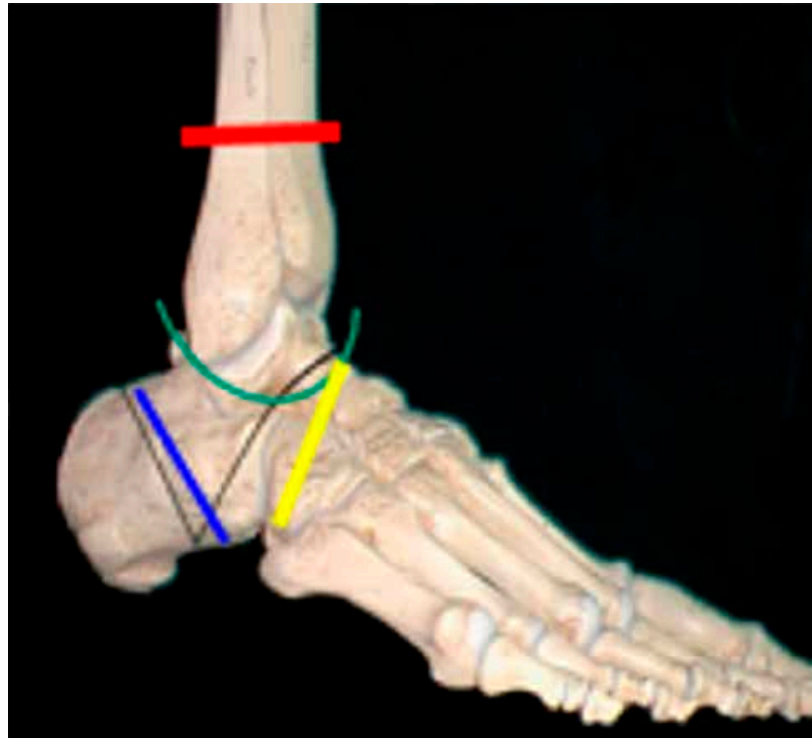

Şekil 6. Ayakta uygulanan osteotomiler.

\section{Ayak Deformitelerin Düzeltilmesinde Uygulanan Osteotomiler (Şekil 6)}

1. Supramalleolar osteotomi (kırmızı çizgi)

2. Talokalkaneal U osteotomi (yeşil)

3. Talokalkaneal V osteotomi (siyah)

4. Posterior kalkaneal osteotomi (mavi)

5. Anterior talokalkaneal osteotomi (sarı)

6. Naviküler osteotomi

7. Metatarsal osteotomi

\section{Pes ekinus}

Ekinus deformitesinin tedavisinde klasik yöntemler, ilizarov yöntemi veya kombine yöntemler kullanılabilir. Klasik yöntemlerde perkütan subtotal aşilotomi, açık $Z$ uzatma veya $V$ uzatma yapılır. ${ }^{[10]}$ illizarov yönteminde hafif orta şiddetli olgularda tibia distaline bir tam halka ve metatarslara bir yarım halka yerleştirilerek aşil tendonu uzatılır; $45^{\circ}$ 'ye kadar şiddetli olgularda tibia distaline iki tam halka kalkaneusa ve ön ayağa birer yarım halka yerleştirilir. Önce tüm rodlar (çubuklar) distrakte edilerek tibiotalar eklem açlır. Metatars ve distal tibial halkayı bağlayan teleskopik rodlar komprese edilirken, distal tibial halka ve kalkaneal halkayı bağlayan rodlar distrakte edilerek deformite düzeltilir. Her gün $3 \mathrm{~mm}$ düzeltme yapılır. Ayak bileği $5^{\circ}-10^{\circ}$ dorsifleksiyona ulaşıncaya kadar düzeltme yapılır. Bu pozisyonda 2-6 hafta beklenir.

Tibiotolar eklem dejenerasyonu ve subtalar eklem dejenerasyonu olan, aynı zamanda supinasyon-pronasyon deformitesinin de düzeltilmesi gereken olgularda ekinus açısı $30^{\circ}-35^{\circ}$ ise $U$ osteotomi; $30^{\circ}-35^{\circ}$ 'den büyük varus, valgus, ön ayak deformiteleri de eşlik ediyor ise $\mathrm{V}$ osteotomi yapılması gerekir. Düzeltmeye ameliyat sonrası 7 . günde başlanır ve günde dört kez $0,25 \mathrm{~mm}$ yapilır.

Sadece ekin deformitesi varsa $U$ osteotomi ile posteriordan distraksiyon ve anteriordan kompresyon ile deformite düzeltilebilir (Şekil 7).

\section{Pes kavus}

Pes kavus sık görülen ayak deformitelerindendir. Genellikle kalkaneal açının $40^{\circ}$ 'nin üzerinde olduğu

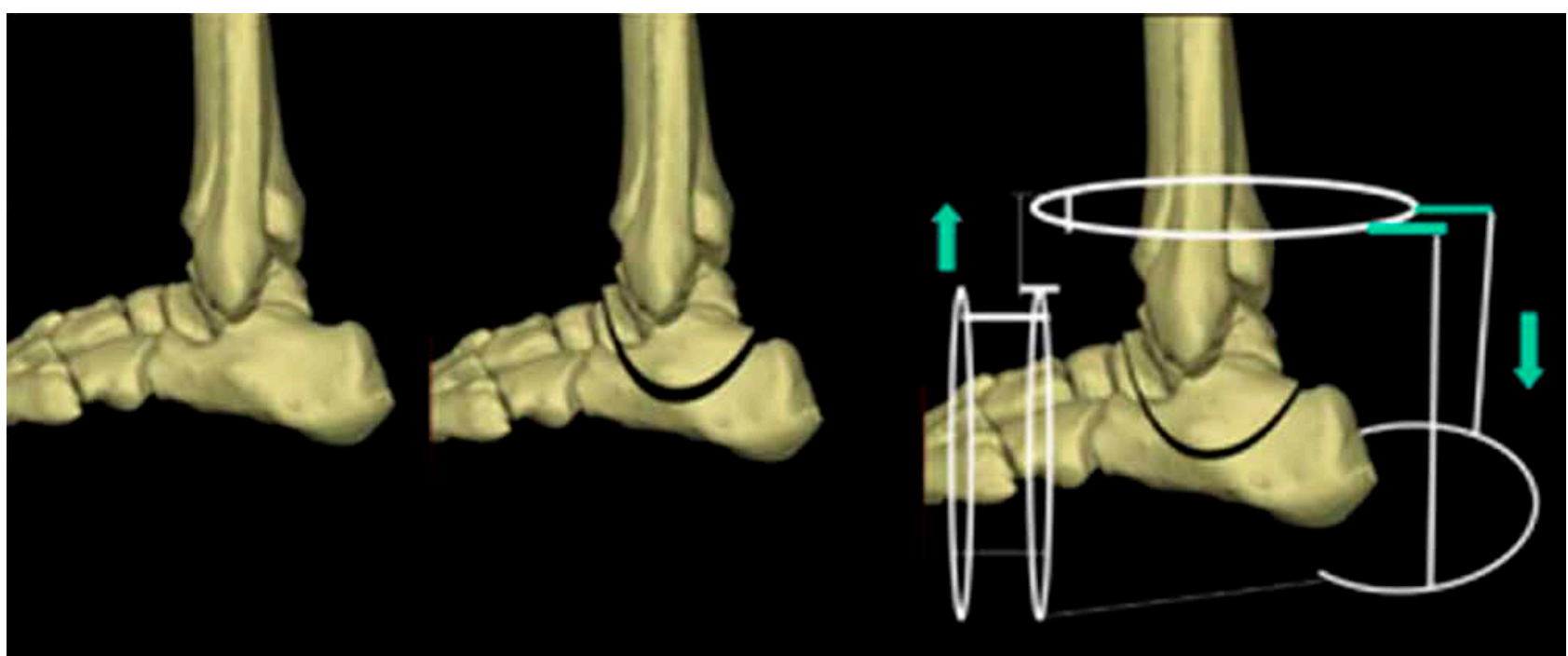

Şekil 7. Pes ekinusta U osteotomi uygulaması. 


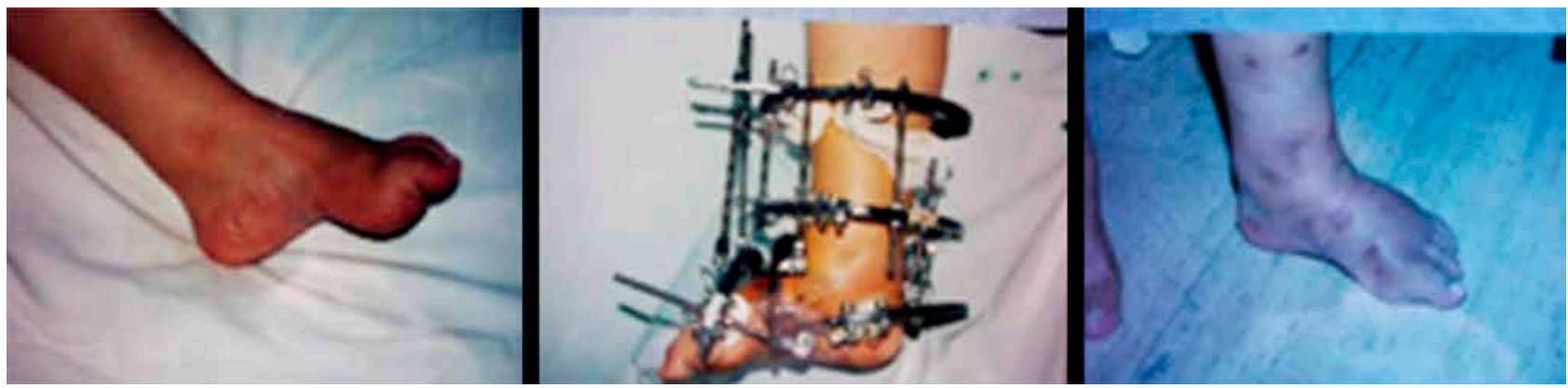

Şekil 8. Pes kavus cerrahi, klinik.

olgularda cerrahi uygulama doğru olur. Bu ameliyattan sonra kalkaneus, talus osteotomileri ve ayaktaki distraksiyonlar bile ağrı sebebi olabilirler. Dolayısı ile yapılan cerrahinin ameliyattan önceki ağrılardan daha mı çok, yoksa daha mı az olacağı iyi değerlendirilmelidir. ${ }^{[3]}$

Birinci derece kavus deformitesi; Gevşek bir pes kavustur. Bunda cerrahi veya ilizarov endikasyonu yoktur. Konservatif tedavi uygulanır.

ikinci derece kavus deformitesi; 1. metatars ekindedir düzelmez. Plantar fasyotomi ve Jones prosedürü uygulanır.

Üçüncü derece kavus deformitesi; Tüm metatarslarda ekin deformitesi vardır. Tüm metatars başları asılır. Topuk varusu Dwyer'in kama osteotomisi ile düzeltilir.

Dördüncü derece kavus deformitesi; -Birinci derece kavusun sertleşmiş halidir. Plantar fasyotomi, Dwyer osteotomisi, Japas'ın tarsal V osteotomisi yapılır.

Beşinci derece kavus deformitesi; ileri derecede sert ayak vardır. "Triple" (üçlü) artrodez yapılır.

Plantar yumuşak dokular tedaviye en dirençli kısımdır. Bu nedenle önce subkütan plantar fasiotomi yapılmalıdır. Tedavide kullanılacak osteotomi, deformite merkezinin Chopart eklemine göre konumu göz önüne alınarak belirlenir. Kavusun merkezi Chopart ekleminin posteriorunda ise talokalkaneal osteotomi, posterior orta ayak kavusu için kuboid-naviküler osteotomi ve orta ayak kavusu için kuboid-naviküler osteotomi tercih edilir (Şekil 8).

\section{Pes planus}

Pes planusta kalkaneus horizontalliğini düzeltici osteotomiler yapılır. Kalkaneus dome (kubbe) osteotomi, açı-kapalı kama ve $\mathrm{Y}$ osteotomisi gibi osteotomiler uygulanabilir. Chopart ekleminin posteriorundaki deformitelerde, arka ve orta ayak deformitelerinin eşlik ettiği durumlarda $\mathrm{V}$ osteotomisi uygulanır.

\section{Pes kalkaneus}

Konjenital formda (konjenital kalkaneovalgus) cerrahiye gerek yoktur. Egzersiz ve alçılama ile iyi sonuç alınır. Pes kalkaneus, dinamik bir deformitedir. Gastroknemius ve soleus kas gücü zayıftır. Bu nedenle tibialis anterior, tibialis posterior, peroneus brevis tendonlarından biri transfer edilebilir veya tibiotalar eklem artrodezi yapılabilir.

\section{Topuk varusu}

Kalkaneus yük taşıma noktasının tibia longitüdinal aksının medialinde olmasıdır. Kalkaneus hipoplastik ise açık kama osteotomisi ile düzeltilmelidir. Hipoplazi yok ve CORA noktası üzerinden düzeltme yapılacaksa kapalı kama osteotomi yapılabilir. Bu yöntemlerde ilizarov yöntemi şart değildir. CORA noktası değil de başka bir yerden osteotomi yapılacak veya kalkaneus uzatılacaksa o zaman îlizarov tekniği kullanılmalıdır.

\section{Topuk valgusu}

Varus deformitesine göre daha tolere edilebilir bir deformitedir. Tedavisi varus deformitesi gibidir.

\section{Pes ekinovarus}

En sık görülen ayak deformitelerinden biri pes ekinovarustur. Genelde küçük yaşlarda açık teknikler ile kolaylıkla ve iyi sonuçlar alınarak tedavi edilir. ${ }^{[11]}$ Fakat yumuşak dokuda oluşacak fibröz dokular ve bunların oluşturduğu yapışıklıklar nedeni ile ayağın büyüme geriliğine, medialde kontraktürlere ve nükslere neden olur. Dolayısı ile nüks PEV vakalarına sık rastlanır. Bu tür vakalarda yeniden açık cerrahi teknik restorasyon hem güç hem de ciltte ciddi problemler oluşturabilir. Illizarov tekniği ile küçük bir insizyondan osteotomi yapabilirken aynı zamandan distraksiyonla cilt problemi oluşturmadan gerdirilebilir.

PEV'de üç ayrı deformite mevcuttur. Pes ekinus, pes varus ve metatarsus adduktus. Sirküler fiksatör bu üç deformiteye uygun olarak ayarlanır. Çerçeve ameliyattan 


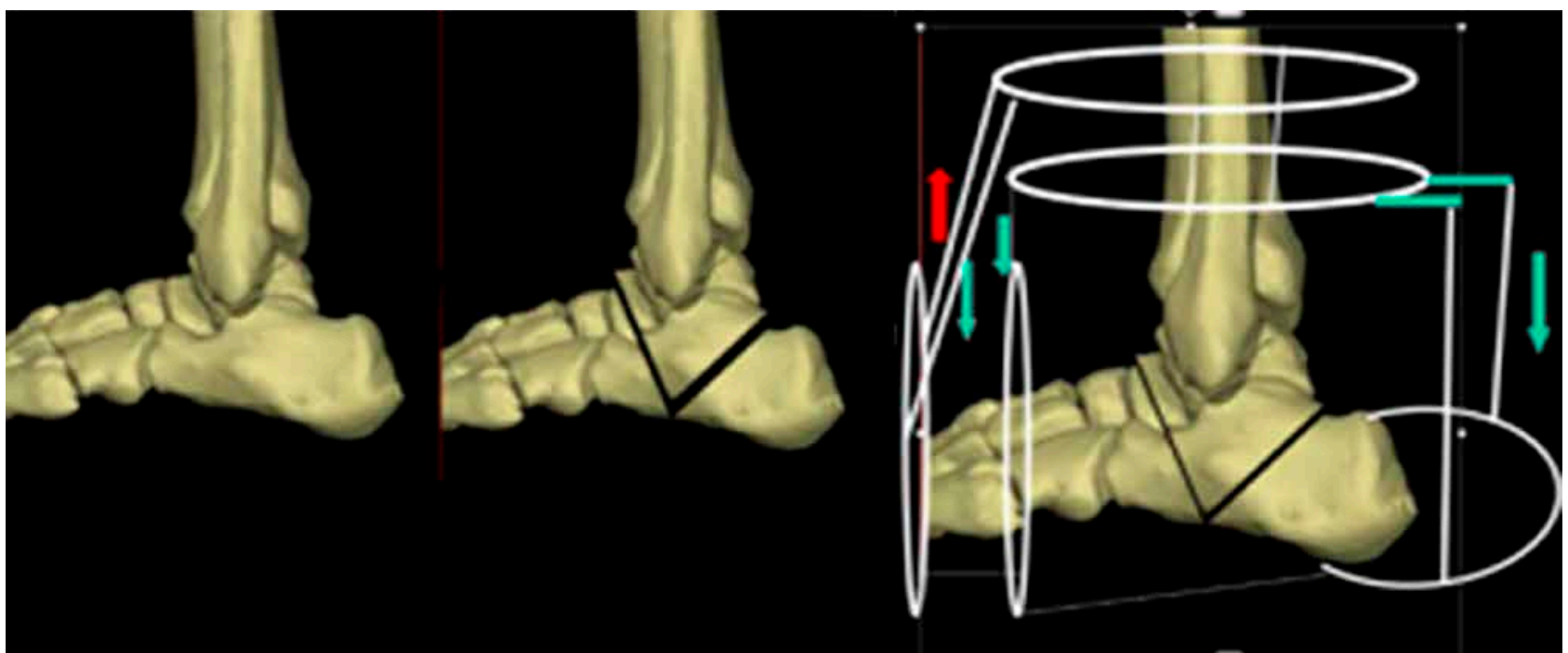

Şekil 9. Pes ekinovarusta kullanılan V osteotomi.
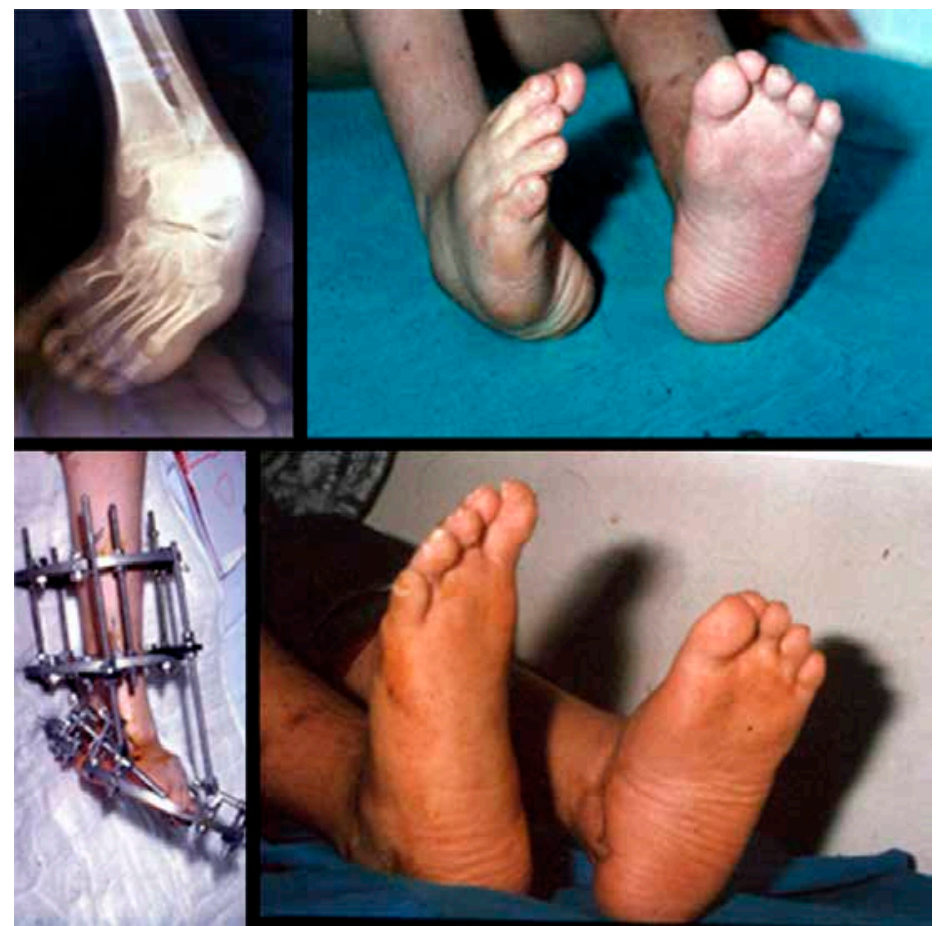

Şekil 10. Pes ekinovarusta radyolojik ve klinik görünümü.

önce ayağa uygun olarak hazırlanır. Uygulama sonrası gerekirse (rijit ve ileri yaş olgular) osteotomi yapılır. PEV de V osteotomi kullanılır (Şekil 9). Çocuklarda beş, ileri yaşlarda 7-8 günlük bekleme sonrası aparat düzeltilmeye başlanır. Aparat düzeldikçe deformite de düzelir. Düzeltme sırası aynı alçılamada olduğu gibi yapılır. Önce metatarsus adduktus düzeltilmeye başlanır. Kalkaneal ve metatarsal halka medialde birbirinden uzaklaştırılarak yapılır. Bu arada yavaşça varus deformitesi de düzeltilmeye başlanır. İki halka birden medialde distale doğru itilerek yapılır. Bu iki deformite düzeltildikten sonra ekin deformitesi düzeltilir. Ekin düzeltmesi, metatarsal halka yukarı çekilerek yapılır. Tam düzelme sonrası üç hafta aparat kilitlenerek beklenir. Üç hafta sonra aparat çıkartılarak üç hafta da alçı tespiti uygulanır. Daha sonra hareket ve rehabilitasyon uygulanır (Şekil 10). 


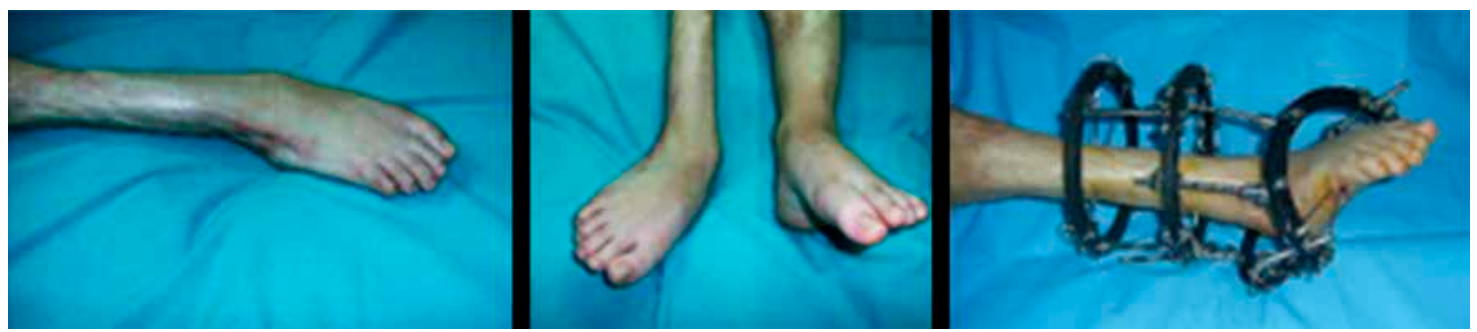

Şekil 11. Yanık skarı ile oluşan ayak deformitesinin ilizarov ile düzeltilmesi.

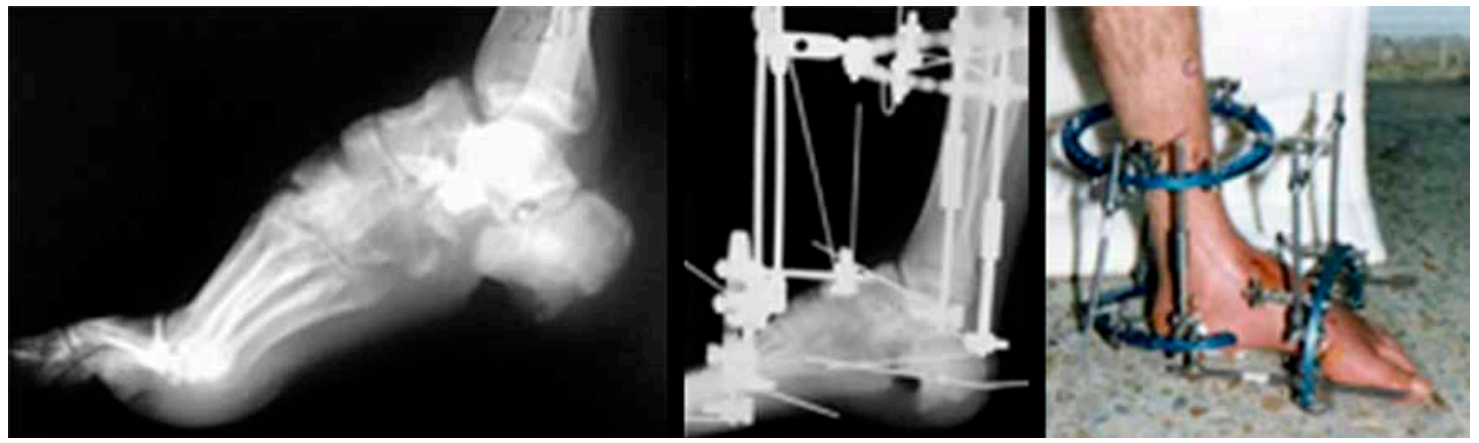

Şekil 12. Travma sonrası gelişen ayak deformitesinin ilizarov ile cerrahisi.
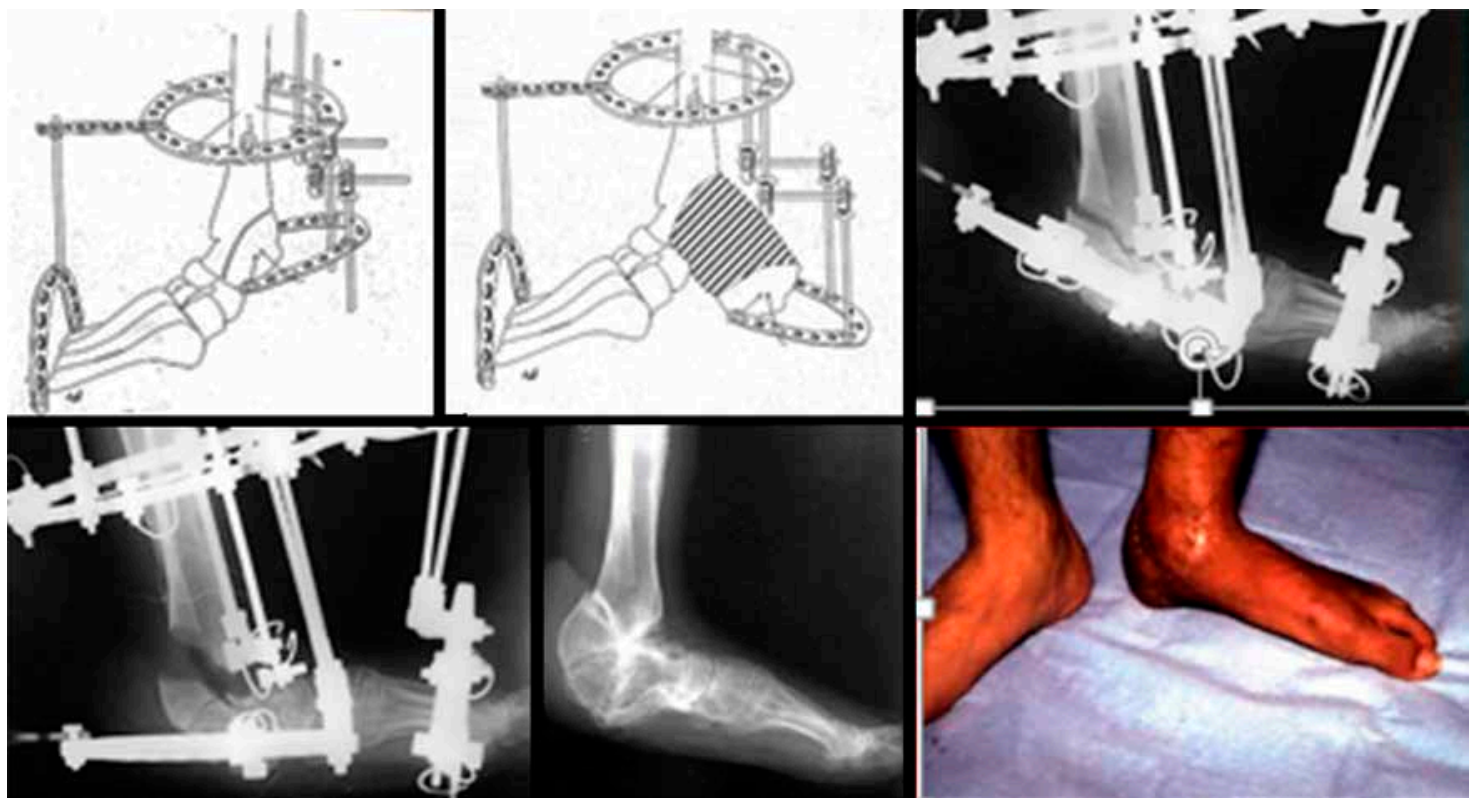

Şekil 13. Mayın yaralanmasına bağlı kalkaneus defekti olan olgunun distal tibia uzatma ile tedavisi.

\section{Diğer deformiteler}

Konjenital (doğumsal) deformiteler dışında edinsel ayak deformitelerinde de sirküler eksternal fiksatörle ile korreksiyon mümkündür. Travma, malunion, nonunion, yanık skarı gibi vakalarda yumuşak doku problemleri de eşlik ettiğinden mini invaziv tekniklerle bu deformiteler düzeltilebilir (Şekil 11). Kalkaneus kırıkları veya ateşli silah yaralanmasına bağlı kalkaneus kayıplarında, kalkaneus uzatma veya tibia distalinden uzatma yapılabilir (Şekil 12 ve 13).

1- Öncelikle midfoot (orta ayak) rekonstrüksiyonu

2- Talus boynu ve midfoot'un tesbiti

3- Tibiotalar artrodez oluşturulması 


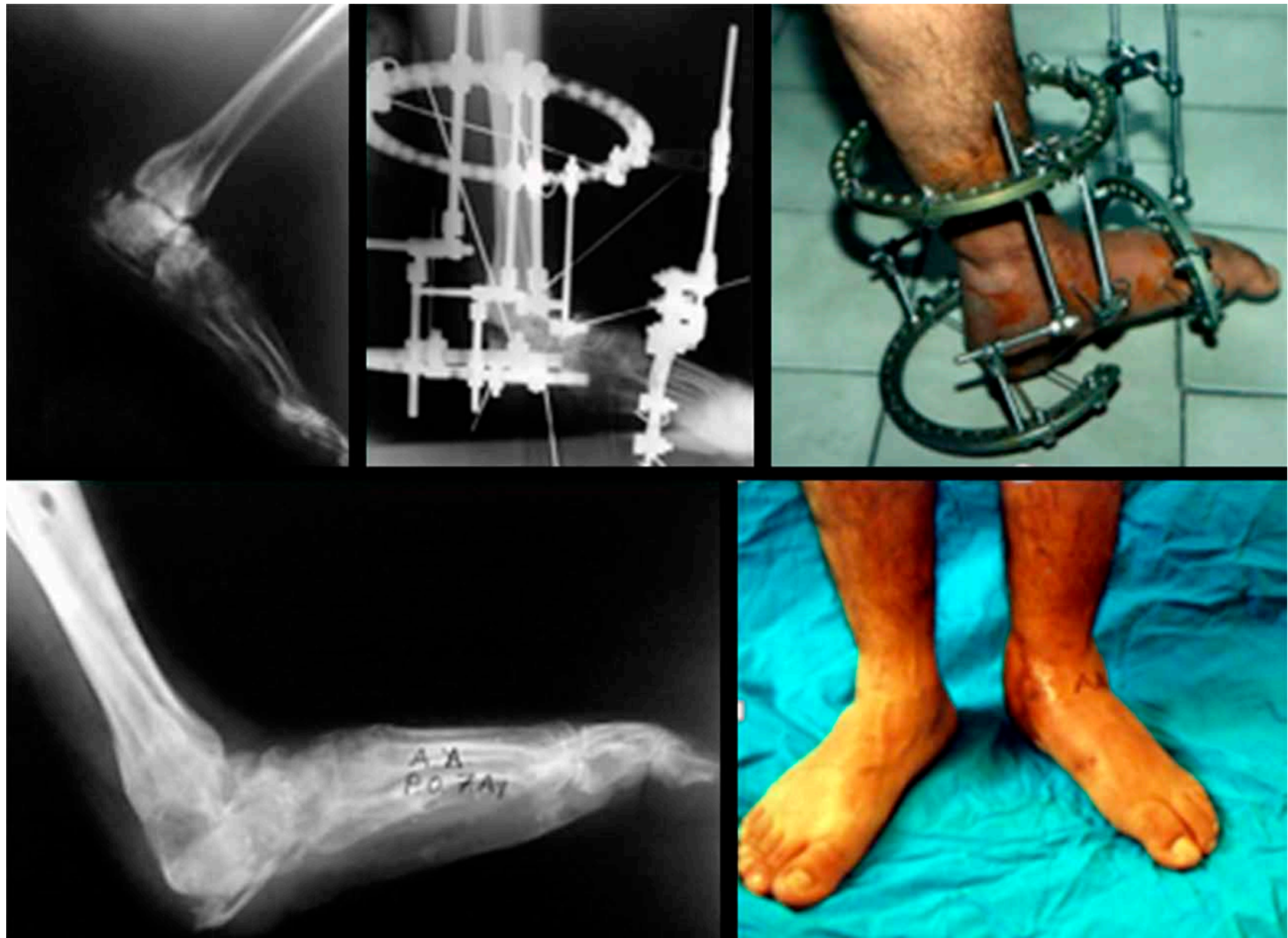

Şekil 14. Kalkaneus uzatma.

Kalkaneus uzatma aparatı kabaca ayak aparatına benzese de sadece kalkaneusa hareket vermek yeterlidir (Şekil 14).

\section{Sirküler Eksternal Fiksatör Uygulanmasında Karşılaşılan Komplikasyonlar}

\section{Ameliyat içi}

1- Nöromüsküler harabiyet

2- Vasküler harabiyet

3- Tel uygulama hataları

\section{Ameliyat sonrası}

1- Pin (Çivi) yeri sorunları

2- Gecikmiş konsolidasyon (kaynama)

3- Erken konsolidasyon (kaynama)
4- Kas kontraktürleri

5- Eklem luksasyonu

6- Aks (Eksen) sapmaları

7- Ağrı

8- Ödem

9- Hatalı distraksiyon

10- Sural sinirin kalkaneal dalının etkilenimi

11- Akut tarsal tünel sendromu

12- Ayak kemiklerinde kist oluşumu

13- İntermetatarsal sinostoz oluşumu

\section{Tedavi sonrası}

1- Nüks

2- Eklem sertliği

3- Neoosteogeneziste impaksiyon 
Ayrıca komplike ayak deformitelerinin düzeltilmesinde, son yıllarda hekzapod fiksatörler de kullanılmaktadır. Takata ve ark. ${ }^{[12]}$, hekzapod fiksatörler ile düzeltme yaptıkları 12 vakalık serilerinde hekzapod-oktopod fiksatörlerin uygulanmasının zor olduğunu, bazı rodların tedavi sırasında kısa kaldığını veya bir biri ile çarpıştığını bu nedenle değiştirilmesi gerektiğini belirtmişlerdir. Multiplanar (pronasyon/ supinasyon, abdüksiyon/addüksiyon ve fleksiyon/ ekstansiyon) hareketlerinin tümünü birden düzeltme olanağı sağlamasını sistemin avantajları olarak belirtmişlerdir. Uzun dönem sonuçları olmaması nedeni ile nüks oranları belirtilmemiş olup, diğer komplikasyonların sirküler eksternal fiksatör ile benzer olduğunu bildirmişlerdir. Simone ve ark.[13], hekzapod sistemle tedavi ettikleri kompleks deformiteli 10 hastanın altısında iyi, ikisinde kabul edilebilir, ikisinde de kötü sonuç bildirmişler ve yöntemin uygulanabilir güvenli bir yöntem olduğunu bildirmişlerdir. Gelecekte daha iyi tasarlanmış yazılımlarla bu sistemlerin daha kullanışlı olabileceği kanaatindeyiz.

\section{Yazarın Notu}

Bu yazıda ön ayak deformiteri kapsam dışı bırakılmıştır.

\section{Teşekkür}

Vaka resim ve çizimlerini bizimle paylaşan Dr. Mustafa Ayas'a çok teşekkür ederiz.

\section{KAYNAKLAR}

1. Kirienko A, Villa A, Calhoun JH. Ilizarov Technique for Complex Foot and Ankle Deformities. New York: Marcel Dekker; 2004.

2. Perry J. Gait Analysis, Normal and Pathological Function. Thorofare, NJ. Slack Inc.; 1992.

3. Ayas M, İlzarov Tekniği ve Uygulama Pratikleri. Ankara: Arkadaş Basım Sanayi; 2013. s.159.

4. Franco AH. Pes cavus and pes planus. Analyses and treatment. Phys Ther 1987;67(5):688-94. Crossref

5. Kocaoglu M, Eralp L, Atalar AC, Bilen FE. Correction of complex foot deformities using the Ilizarov external fixator. J Foot Ankle Surg 2002;41(1):30-9. Crossref

6. Torun Bi, Çay N. Ayak Arkus Açısı ve Ayak Uzunluğu Arasındaki Illişki. Kafkas J Med Sci 2018;8(3):172-7. Crossref

7. Jankowicz-Szymanska A, Mikolajczyk E, Wardzala R. Arch of the foot and postural balance in young judokas and peers. $J$ Pediatr Orthop B 2015;24(5):456-60. Crossref

8. Wozniacka R, Bac A, Matusik S, Szczygiel E, Ciszek E. Body weight and the medial longitudinal foot arch: high-arched foot, a hidden problem? Eur J Pediatr 2013;172(5):683-91. Crossref

9. Demiralp B, Kürklü M, Bek D, Yurttaş Y, Ateşalp AS. The treatment of comminuted midfoot fractures with distraction osteogenesis. Acta Orthop Traumatol Turc 2004;38(2):1305. http://www.aott.org.tr/en/the-treatment-of-comminutedmidfoot-fractures-with-distraction-osteogenesis-164854

10. Çakmak M, Yıldız F, Sungur M. Ayak bileği ve ayak deformitelerinin Ilizarov yöntemi ile tedavisi. TOTBID Derg 2010;9(4):213-50. https://docplayer.biz.tr/53303435-Ayakbilegi-ve-ayak-deformitelerinin-ilizarov-yontemi-ile-tedavisi.html

11. Hosny GA. Correction of foot deformities by the Ilizarov method without corrective osteotomies or soft tissue release. J Pediatr Orthop B 2002;11(2):121-8. Crossref

12. Takata M, Vilensky VA, Tsuchiya H, Solomin LN. Foot Deformity Correction with Hexapod External Fixator, the Ortho-SUV Frame. J Foot Ankle Surg 2013;52(3):324-30. Crossref

13. Riganti S, Coppa V, Nasto LA, Di Stadio M, Calevo MG, Gigante AP, Boero S. Treatment of complex foot deformities with hexapod external fixator in growing children and young adult patients. Foot Ankle Surg 2019;25(5):623-9. Crossref 